AS ATIVIDADES LABORATORIAIS CONTRIBUEM PARA UMA CONCEPÇÃO CONTEMPORÂNEA DA CIÊNCIA NA FORMAÇÃO INICIAL DE PROFESSORES?

\title{
DO LABORATORY ACTIVITIES CONTRIBUTE TO A CONTEMPORARY CONCEPTION OF SCIENCE IN INITIAL TEACHER TRAINING?
}

\section{¿LAS ACTIVIDADES DE LABORATORIO CONTRIBUYEN A UNA CONCEPCIÓN CONTEMPORÁNEA DE LA CIENCIA EN LA FORMACIÓN INICIAL DEL PROFESORADO?}

\author{
VALENCIA, Katerin'; SANJOSÉ, Vicente ${ }^{2}$; TORRES, Tarcilo ${ }^{3^{*}}$; \\ 1,3 Universidad de Antioquia, Facultad de Educación, Departamento de Ciencias y Artes \\ 2Universidad de Valencia, Departamento de Didáctica de las ciencias experimentales y sociales. Grupo CDC. \\ * Correspondence author \\ e-mail: tarcilotorresvalois@gmail.com
}

Received 11 December June 2018; received in revised form 28 July 2019; accepted 06 August 2019

\section{RESUMO}

Neste estudo analisamos a implementação de atividades laboratoriais na formação inicial de professores de ciências e como elas contribuem para a construção de uma visão contemporânea da natureza da ciência. Um estudo não experimental e sincrônico foi desenvolvido entre o primeiro e o oitavo semestre de dois cursos de graduação de formação inicial de professores em uma universidade na Colômbia. Analisamos nove disciplinas científicas (física, química e biologia) do currículo. Os resultados indicam que as atividades laboratoriais analisadas focaram no desenvolvimento de técnicas e procedimentos pré-definidos, dando pouco destaque à criatividade, dúvida, discussão, planejamento e aplicação, ainda que sejam atividades características do trabalho científico. Essas atividades de laboratório não parecem favorecer a construção de uma concepção contemporânea da natureza da ciência.

Palavras-chave: Ensino de Ciências Experimentais; Formação de professores de ciências; Natureza das ciências; Práticas de laboratório

\begin{abstract}
In this study, It was analyzed the implementation of laboratory activities in the pre-service science teacher's training and how they contribute to the construction of a contemporary epistemic vision of the nature of science. A cross-sectional study was developed in two different undergraduate programs of pre-service science teacher training in a university in Colombia of. We analyzed the way laboratory activities are developed in nine science subjects of physics, chemistry, and biology, apart from the first to the eight semesters of the curriculum (10 semesters in total). Results indicate that the laboratory activities focused on the development of pre-defined techniques and procedures, giving little prominence to creativity, doubt, discussion, planning, and application, even though they are also characteristic activities of scientific work. This kind of laboratory activities does not seem to favor the construction of a contemporary conception of the nature of science in future science teachers.
\end{abstract}

Keywords: Teaching experimental sciences; Science teachers' training; Nature of Sciences; Laboratory practices.

\section{RESUMEN}

Pese a la importancia de las prácticas de laboratorio para la comprensión de la naturaleza de la ciencia, el modo en que la ciencia se crea y valida, generalmente las actividades de laboratorio realizadas en contextos académicos no enseñan el auténtico trabajo de los científicos. En este estudio se analizó la implementación de las actividades de laboratorio en formación inicial de profesores de ciencias, y el modo en que contribuyen a la construcción de una visión contemporánea de la naturaleza de la ciencia. Se desarrolló un estudio no 
experimental y sincrónico entre el primer y octavo semestre de dos pregrados de formación inicial de profesorado de una universidad en Colombia. Se analizaron nueve materias de ciencias (física, química y biología) del plan de estudios. Los resultados indican que las actividades de laboratorio analizadas se centraron en el desarrollo de técnicas y procedimientos prefijados, dando poco protagonismo a la creatividad, la duda, la discusión, la planificación y la aplicación, aun cuando son actividades características del trabajo científico. Estas actividades de laboratorio no parecen favorecer la construcción de una concepción contemporánea de la naturaleza de la ciencia.

Palabras claves: Didáctica de las Ciencias Experimentales; Formación de profesores de ciencias; Naturaleza de las Ciencias; Prácticas de laboratorio.

\section{INTRODUCTION}

Current citizens need to be scientifically literate. For Miller (1983) this means: (1) an understanding of the processes and methods of science to test the models of reality that are constructed; (2) a certain mastery of the terminology and the underlying scientific and technical concepts; and (3) the understanding of the impact of science and technology on society in order to make decisions on issues that affect all the citizens. The first two dimensions refer to knowledge about science, and the third one implies responsible application in social settings of daily life. However, to be able to do the latter, citizens need to build some criteria (an activity of high cognitive requirement, according to Bloom's taxonomy). Building a useful criterion to make decisions about scientific issues requires knowledge of how scientific knowledge is elaborated and validated (Jian-Xin, and Yu-Ying, 2017). Summing up, to be scientifically literate citizens have to understand the Nature of Science (NOS onwards) (Abd-El-Khalick et al., 2004).

In addition, students' knowledge about NOS influences their learning of scientific concepts (Clough, 2011). Some studies on epistemic knowledge of in some university students in the laboratory of biology concluded that participants with constructivist views of NOS learned more about scientific concepts than students who possessed positivist views (Wallace et al., 2003; Cian Marshall and Qian, 2008).

Despite the importance of adequate knowledge on NOS, and of its influence on science concept learning, teachers and students often have naïve views about the construction and validation of scientific knowledge (Kang \& Wallace, 2005, Lederman, 2007, Sarieddine \& BouJaoude, 2014).

Naïve views on NOS are implicitly (or even explicitly) transferred to the classrooms in the form of teaching approaches, as the transmission- reception method (Gil, 1986).

Offering a "finished" knowledge to students means avoiding the process of construction and validation of that knowledge, that is, the way in which scientists work. Traditionally, performing laboratory experimental activities (LA onwards) have been used to demonstrate principles and laws previously stated, via reproductive procedures. Thus, in this paradigm, activities in the laboratory are implemented as a pre-defined sequence of actions that, once properly executed, necessarily lead to the scientific understanding of the phenomena. There is evidence that this conception of LA does not lead to proper knowledge of NOS (Lederman, 2007, Yacoubian, and BouJaoude, 2010). In fact, the degree of familiarity with scientific methodology achieved by students through the traditional LA is so scarce that hardly allows them to recognize key aspects such as the hypothesis generation or the experimental design (Gil y Payá, 1988).

\section{Laboratory activities in science teaching}

Throughout the history of science education, the educational purpose of LAs is very varied. The term "laboratory activities" or "laboratory experiences" has been used to describe the teaching and learning that takes place in special spaces (the Labs) or in the natural environment (Singer, Hilton, and Schweingruber, 2005; Abrhams and Reiss (2012) consider that "LA is a term that refers to any type of teaching and learning activity in which students, working either individually or in small groups, are involved in the manipulation and / or observation of real and material objects "(p. 1036). Lunetta, Hofstein, \& Clough, (2007) conceive LA as learning experiences in which students interact with materials or secondary sources of data to observe and understand the natural world. Leite and Dourado (2013) affirm that practical work has to do with practical activities that require active and cognitively engaged students. This last definition 
makes explicit that LAs cannot be reduced to the reproduction of procedures or recipes, but they involve activities of greater cognitive complexity.

However, certain problems have been pointed out in the way in which LAs are implemented in academic spaces (Abrahams and Millar, 2008, Hodson, 1994), as lack of clear objectives or little orientation towards student research, among others (Lunetta et al., 2007). Certain LAs are widely questioned because the student is able to perform them without meeting the learning goals, such as social and technical skills, construction of concepts, the discovery of facts about science, learning problem-solving skills, and deep understanding of NOS (Dekorver and Towns; 2016).

When LAs are developed into an instructional approach based on transmitting finish knowledge, LAs are used to "check science laws". Then students generally follow a "cooking recipe", make little use of scientific skills, and are rarely involved in hypothesis and questioning. The traditional "activist" way of implementing the LA focuses on the execution of procedures and does not encourage the student to use their theoretical knowledge to interpret the phenomena (Abrahams and Millar, 2008). Therefore, they do not contribute to knowledge about NOS (Lunetta et al., 2007). Moreover, Carrascosa, Gil Pérez, and Vilches (2006) consider that the experimental work, not only has a poor presence in the teaching of science, but the orientation of the few practices carried out contributes to a distorted and impoverished vision of the scientific activity. Therefore, it is necessary for a deep re-orientation. According to these authors, the empiricalinductivist conception of science and scientific work has a great weight in science teachers and linked to it, the common deformation that identifies the methodology of scientific work with the realization of experiments. However, along with this conception, there are others, such as the individualistic and elitist vision, the decontextualized, etc. (Carrascosa et al., 2006).

In modern approaches to science education, conceptual as well as procedural and epistemic (NOS) aspects have been reconceptualized so that they are not treated separately. "In other words, what the research is showing is that the meaningful understanding of concepts requires overcoming conceptual reductionism and proposing the teaching of science as an activity, close to scientific research, which integrates the conceptual, procedural and axiological "(Vilches \& Gil Pérez, 2007, p. 74). The LA, therefore, become small investigations in which students are put in place of "novice researchers" who follow mental procedures similar to those followed by scientists, although using simplifications that today are protected under the broad umbrella of Inquiry Learning. This science teaching approach allows students to learn close to the way scientists learn, and to develop science skills, such as question-asking and hypotheses generation, argumentation, etc. Summing up, this approach fosters students' understanding of the nature of science, as it is conceived nowadays (Hofstein, Navon, Kipnis, \& Mamlok-Naaman, 2005, Yacoubian \& BouJaoude, 2010).

The constructivist conception of the teaching of science promotes the understanding of science through the personal and social construction of meanings. Within this constructivist conception of learning, theory and practice (the concepts and laws and processes of science) are linked in an indissoluble way (Gil Pérez \& Valdés Castro, 1996 ; Gil Pérez, Martínez Torregrosa, \& Vilches Peña, 2008) A vision like this allows LAs to be recognized as practices that favor students' greater understanding of the process of building scientific knowledge (Dillon, 2008; Hofstein \& Lunetta, 2004; Millar, 2009) and even student learning (Hofstein et al., 2005).

Vhurumuku, Holtman, Mikalsen, and Kolsto (2006) found that some LAs implicitly promoted misconceptions about NOS. Therefore, not every way of LA implementation serves the aforementioned purpose of NOS literacy. However, there is experts' agreement: implemented in a way coherent to the constructivist approach to science learning, LAs should contribute directly to the NOS knowledge of students (Vhurumuku et al., 2006, Lunetta et al., 2007, Kang and Wallace, 2005).

In that way, LAs that emphasize learning through research and discovery, and encourages students to learn through the discovery of the phenomena, can contribute to citizens scientific literacy (Schwichow et al., 2016), not only in epistemic issues but also as scientific knowledge concerns, (Fadzil and Saat, 2017).

\section{Objective}

Despite the knowledge about fruitful ways of implementing LAs in science education, in the training of science teachers some educational centers continue to develop LA in a traditional way, without taking into account their integration with other formative activities of scientific education, such as problem solving (Peltier and Vannest, 2017; Jitendra et al., 2015;) learning by inquiry (Lazonder and Harmsen, 2016; Pedaste et al., 
2015) or understanding of aspects about NOS (Lederman and Lederman, 2014).

Pre-service teachers are similar to other students when they are not properly trained. Kang and Wallace (2005), found that some teachers have naive epistemological beliefs of NOS, which are reflected in the practices they propose to their students. Moreover, when teachers had an adequate understanding of NOS, they did not necessarily integrate this knowledge into the instruction (Bell, Lederman, and Abd-El-Khalick, 2000). Therefore, teachers need to be instructed in NOS issues too, in order to make them conscious of appropriate and inappropriate ways to educate their students in science.

Changes in teacher training programs devoted to explicitly deal with their NOS conceptions and debate about them in a constructivist context, have achieved good results: teachers' changes in NOS visions cause other changes in the activities they propose to their own students (Akerson, Abd-El-Khalick, \& Lederman, 2000; Lederman, Antink and Bartos, 2014; Pekbay and Yilmaz, 2015).

Therefore, whether science teachers have, or do not have, a good command of NOS can influence the image, adequate or distorted, of science they transmit to their students, but also the way they conceive the instructional goals and manage the educational activities. Teachers' proficiency in NOS depends on how they received their initial and ongoing training (or in-service). In the case of initial training, NOS training should be directly related to the laboratory activities (LA) that are carried out during scientific-disciplinary training, but also in didactic training.

Given the relevance of teachers' learning about NOS, and their relationship to inquiry learning approaches (Wallace et al., 2003), the goals of the present study are

1) To analyze the way LA are implemented in pre-service science teachers training, looking for features related to epistemic issues.

2) To Identify NOS conceptions in preservice science teachers.

Hence, we will analyze LA in order to infer whether they can contribute to an adequate vision of NOS in future science teachers. In addition, we also aimed at:

3) To analyze whether or not the NOS conceptions vary along with the pre-teacher training program.

\section{Hypothesis}

In relation to our objective, the hypotheses that are posed to contrast are formulated as follows:

$\mathrm{H} 1$ : The laboratory activities carried out by science teachers in initial training will show a constructivist conception of the nature of science.

We expect that the LA in the pre-service science curricula show science as a product of human construction, with values and influenced by a context and a culture, and include historical and epistemological components. Hence, LA proposed should allow future teachers to question asking, hypotheses formulation, experimental design, collaborative learning, discussion and meaning negotiation, and public explanation of the whole process.

$\mathrm{H}$ 2: Future teachers in the last semesters have participated in more science subjects than those of the first semesters. It is also expected that more pedagogical-type courses would imply a better conception that should contribute to a better understanding of the nature of science than students in initial semesters.

\section{MATERIALS AND METHODS}

This research is non-experimental, synchronous, and descriptive. It is based on the direct observation of the situation to be investigated, as it is developed without manipulating the variables that intervene and influence. The data collection only occurs in a single period. The data will be quantified whenever possible, and the analyzes will be based on this quantification.

\subsection{Participants}

Information was obtained from 9 subjects in which 116 students from two initial teacher training degrees of science teachers were enrolled. The participants, of both sexes, were enrolled between the third and tenth academic semester in a public university. The teachers in formation found themselves involved in the realization of laboratory practices in different subjects. In total, 57 laboratory practices were observed in 9 different subjects, with the following distribution: $36.20 \%$ were physics; $34.5 \%$ chemistry, and $29.3 \%$ biology. Table 1 shows the number of participants and laboratory practices by subject and by degree. 


\subsection{Materials for data collection}

For the data collection, 3 different instruments were used that were selected for their psychometric characteristics and their functionality. 1) Rubric to characterize the levels of inquiry that have the laboratory practices of Buck, Bretz, and Towns, (2008). Five levels are considered depending on how close the practice of authentic scientific research is: confirmation level, structured activity, guided research, open research, and authentic research. 2) Inventory to Evaluate Laboratory Activities (LAI) by Tamir and García (1992). This instrument is composed of 25 items that describe the activities of four processes that are carried out in the laboratory: planning, implementation, analysis, and application. 3) Questionnaire for the identification of Conceptions about Science, Models, and Scientific Modeling in the context of Physics (Vasques Brandão, Solano Araujo, Veit, and Lang da Silveira, 2011). The questionnaire consists of 48 items that explore the thinking of each participant about: the nature of scientific knowledge, construction, and validation of scientific knowledge, nature, and function of scientific models, and construction and validation of scientific models. Annex I contains examples of items for each of these instruments.

\subsection{Variables and measures}

Three independent variables are considered: a) type of degree in teaching staff (Mathematics and Physics / Natural Sciences); b) Academic level or semester of each student; c) Matter (each of the 9 in the sample). The dependent variables were the conception about the nature of the science, the number of recurrences of each statement, and the total count of the activities carried out in each laboratory and the level of inquiry of the guide.

Three independent variables are considered: a) type of degree in teaching staff (Mathematics and Physics / Natural Sciences); b) Academic level or semester of each student; c) Matter (each of the 9 in the sample). The dependent variables were the conception about the nature of the science, the number of recurrences of each statement, and the total count of the activities carried out in each laboratory and the level of inquiry of the guide.

\subsection{Procedure}

The information-gathering was carried out during an academic semester. The respective permits were requested from the professor in charge of the laboratories in each degree, the teacher of each subject and the teachers in initial training participants. In each laboratory session, the students are organized by their teacher in small groups that share the same experimental work. The procedure was the same in all subjects and consisted of attending each of the laboratory spaces and non-participant observation of the development of the activities of different groups of students in each subject, as shown in Table 1.

At the beginning of each laboratory activity, the work guide delivered to the students was obtained, and the level of inquiry was analyzed through the rubric of Buck, Bretz, and Towns, (2008). Then, the activities that all the participants performed and the LAI instrument (Tamir and García, 1992) were diligently observed to characterize the forms of implementation of the laboratory activities in each observed group. Finally, once the observation phase was completed, and all the data included in the LAI were completed, each laboratory professor was asked to provide the mandatory reports made by each group. Once all the laboratory sessions were concluded, the questionnaire of Conceptions on the nature of science was applied to the participants (Vasques et al., 2011).

All participants were informed of the research objectives at the beginning, the type of data that each instrument collects, and the particular way of completing the questionnaires at each appropriate time.

\subsection{Processing of data}

The collected data were organized in an Excel sheet and then analyzed by descriptive and inferential analysis with the statistical package SPSS version 21.

\section{RESULTS AND DISCUSSION:}

\subsection{Description of laboratory activities in the training of science teachers}

The descriptive analyses indicate that of the 57 activities observed, 44 are of the guided research type, 7 of confirmation, and 6 structured research according to the classification of Buck et al. (2008). The type of most common practice in the activities analyzed is characterized by having a guide that provides the problem, the theory, and 
the procedure. Then with these elements, the teacher in training must analyze the results and build the conclusions of the experience.

Regarding the activities carried out by the participants within the laboratories, Table 2 shows that the highest average is obtained by the category of "Realization" ( $\mathrm{M}=2.11, \mathrm{SD}=2.50)$, as opposed to the category of "Application" that obtained the lowest average $(\mathrm{M}=0.05, \mathrm{SD}=$ $0.27)$. The most frequent activity carried out by the participants was that of "record results" (205 times) followed by that of "extract interrelations" (194 times). The reason for this is that the laboratory guides are pre-prepared and the teachers in training only follow processes that do not merit planning, but merely the application of a pre-established procedure.

Additionally, laboratories are structurally very similar in the three disciplines analyzed. This is evidenced by the fact that the averages of the categories of realization and analysis are always the highest and those of planning and application the lowest in each course, regardless of the discipline or semester to which they belong (Table 2). In addition, during the observation, the 57 practices presented the same implementation protocols that consisted of 3 moments: first explanation of the teacher in charge, the second performance of the procedures and third completion of the report.

These results suggest that in the laboratory practices analyzed, activism prevail, and the processes of authentic scientific research are not encouraged: generation of research questions, design of a study to address the research question, making observations, explaining results and analysis of other investigations (Chinn and Malhotra, 2002).

Table 3 shows the averages obtained in each instrument item according to the semester and the degree. In this case, it can be observed that in each subject and semester, the averages have similar behavior in each of the categories. For example, in the Application category, the averages of each of the activities are zero, mostly in all subjects, regardless of the semester. It should be noted that in the degree in natural sciences there are two courses that belong to the third semester so in the table, the differentiation is made as follows: M3 means microbiology and Q3 analytical chemistry.

Unlike other categories such as the realization where the values of the means to reach up to 7 or the analysis whose values are in a range of 0 to 3 . This indicates that laboratory activities focus on procedures and reporting. What leads to rejecting the $\mathrm{H} 1$, since the practices leave out other activities of the scientific work such as the application of results, solution of new problems, predictions from others.

\subsection{Conceptions about the nature of science that teachers in training have}

Figure 1 shows the distribution of the averages obtained in the sample. It is observed that $62 \%$ of the students have averages above 3 (scale Lickert 1-5), indicating slightly constructivist positions in response to the statements proposed by each item of the instrument. The highest mean was $(M=4.23, S D=0.26)$ and the lowest was ( $M$ $=2.15, \mathrm{SD}=0.18)$.

In addition, $23.08 \%$ of the items obtained an average of less than 2.5. $49.14 \%$ of teachers in training obtained an average below 3 and only $6.90 \%$ a total average greater than or equal to 4 .

Now, to compare if there are differences between the conceptions on nature of the science that the teachers in formation have in the different courses, the distribution of the data is analyzed initially. According to the Shapiro Wilk test, there was no significant difference between the observed distribution and a theoretical Gaussian ( $p>0.05$ ), so parametric statistical tests were used in subsequent analyses.

An ANOVA analysis was performed for the averages in Conceptions on NOS taking the subject as an independent factor. There were significant differences between the semesters analyzed $\left(F(8,107)=2.86, p<0.05, \eta^{2}=0.18\right)$. The most advanced semester courses have a higher average, which means that these participants have more constructivist thinking compared to the participants of initial semesters. For example, the physics course of the first semester movement has a lower average $(\mathrm{M}=$ $2.98, \mathrm{SD}=0.16)$ than the eighth-level ecology course $(\mathrm{M}=3.61, \mathrm{SD}=0.25)$. When comparing the type of vision (empiricist or constructivist) with the semester of the participant, it is found that in the initial semesters the number of teachers in training with empiricist vision is higher than participants with constructivist vision.

In addition, the empirical-inductivist positions tend to disappear in the more advanced semesters (figure 2). Proof of the impact of the formation of the two degrees to the understanding of the nature of science. However, it should be considered that both degrees must continue working on the teaching of the nature of science because as evidenced by the figure there are still students of advanced semesters with naive views 
of science.

Finally, when comparing the type of vision (empiricist or constructivist) with the semester of the participant, it is found that in the initial semesters the number of teachers in training with empiricist vision is superior to that of teachers with constructivist vision. In addition, it is evident that the empirical-inductivist positions tend to disappear in the more advanced semesters, as shown in figure 2.

This is an indication that the scientific education received by the participants of both degrees is influencing the students' thoughts by showing a science product of human construction, influenced by social, historical, and cultural processes.

\subsection{Relationship between conceptions about the nature of the science of teachers in initial training and the development of laboratory activities}

The last objective consisted of contrasting the visions on the nature of the science of the participants with the type of laboratory activities carried out. Table 4 allows to compare the averages of the participants in conceptions about NOS, and in categories associated with the character of each laboratory activity and its execution. It can be seen that the behaviors of the different variables are different, the NOS averages increase after the semesters have elapsed. In initial levels, the means vary from 2.73 (microbiology) to 2.98 (Physics of movement) compared to the final semesters, whose means are around 3.61 (Ecology). While the average pattern of laboratory activities regardless of discipline and semester, are higher in the category of achievement (averages above 0.88) and analyzes (averages above 0.88).

It should be noted that this pattern of means by category of laboratory activities is not only influenced by the conceptions of the nature of science but also seems to be due to factors such as the planning of these practical activities, the number of sessions carried out and a number of teachers in training. For example, the physics course of the movement with 14 participants and 8 practices has high averages in the categories with respect to genetics with 22 participants, but with only 5 laboratory sessions. This makes sense because the greater the number of practices, the procedural, analysis, and planning activities will be greater.

Due to this fact, the results apparently indicate that the laboratory activities contribute little to improve the understanding of the nature of science in the teachers in training. Because of their characteristics and forms of development, these practices are adhered to the procedures of the guides. Thus, the laboratory activity implicitly shows a vision of science where contemporary reflections of history and epistemology are not taken into account. Reflections that aim to consider science as a human construction, influenced by context; whose progress depends on subjectivity and creativity, an activity where peer-to-peer discussions are fundamental to evolve (Lederman \& Lederman, 2014).

\section{CONCLUSIONS}

The first objective of the present study was to describe the way in which laboratory activities are developed in pre-service science teachers training. Specifically, we aimed at identifying the type of practice that is carried out in the LABs. The results showed that the most frequent types of practices are those related to the application of pre-established procedures, followed by those that have to do with some type of analysis. Descriptive analyzes allowed describing the characteristics and type of LAB practices that are performed. Similarly, to determine the conceptions of NOS, an analysis of variance was carried out. On the other hand, the least carried out LA are those related to planning and its application to other contexts (transfer of scientific skills).

Therefore, hypothesis $\mathrm{H} 1$ : The laboratory activities carried out by science teachers in initial training will show a constructivist conception of the nature of science, was not supported by the data collected.

Most of the observed and analyzed LA in the Bachelor's degrees in Natural Sciences and Mathematics and Physics had structured procedural guidelines where data collection is mainly favored, and other important skills, as the formulation of questions, the experimental design and application of results in other contexts are neglected systematically.

These results are similar to the problems shown by the literature for the implementation of the LA in other countries (see, Abrahams and Millar, 2008, Millar, 2009, Sandoval and Reiser, 2004).

Regarding the second objective, which consisted of identifying the NOS conceptions of future science teachers, the results showed that their conceptions about NOS have a slight tendency toward constructivist visions about the 
production of scientific knowledge. Specifically, the views on NOS identified in participants indicate that they have developed some understanding about the temporary and unfinished character of science, the progress in scientific explanatory power, and the importance of the scientific community for the development of knowledge.

However, some participants showed naive conceptions about NOS. They showed features of the empiro-inductivist and naive conception of Science, a merely cumulative conception of scientific development, as expressed by some authors (Fernandez et al., 2002; Gil Pérez, Martínez Torregrosa, \& Vilches Peña, 2008): empirical observation is the starting point of science knowledge, thus, conducting experimental work is the only way to learn science, experimentation follows observation and is articulated in well-known, and established steps (observation, experiment, measures, interpretation, knowledge); science laws are straightforward consequences of experimentation, etc.

These results are consistent with those found in the literature and, at the same time, it is suggested that explicit reflection on NOS allows us to improve your understanding. However, the literature also shows that there are still limitations on the understanding of NOS (İrez, Çakir, \& Şeker, 2011).

In this way, we can say that the pre-service teacher training degrees analyzed allow teachers to develop an understanding of NOS, but it is still necessary to delve a little deeper.

According to objective 3 , results also indicate that in the initial semesters there are more teachers with empirical-inductivist conceptions of science; while this number is reduced in the advanced semesters of the Degree in Natural and Mathematical Sciences and Physics. This indicates that professors of advanced semesters have more constructivist features in their view of science than professors in initial semesters who, in turn, present more empirical-inductivist features in their views of science.

Therefore, hypothesis H2 was supported by the data.

Summarize the data discussed in the Results and Discussion showing the relevance of the work and how different it is from other researches. Also, point out the benefits and improvements that can be observed in order to develop new scientific standards that can change something in the related field.

\section{REFERENCES:}

1. Abrahams, I.; Millar, R. IJSE. (2008), doi.org/10.1080/09500690701749305.

2. Akerson, V. L., Abd-El-Khalick, F.; Lederman, N. G. JRST, 2000,37, 295.

3. Bell, R. L., Lederman, N. G.; Abd-ElKhalick, F. JRST, 2000, 37, 563.

4. Buck, L. B., Bretz, S. L.; Towns, M. H. JCST, 2008 , 38, 52.

5. CarrascosA, J. Gil-Pérez, D.;Vilches, A. CBEF. 2006, 23, 157.

6. Chinn, C. A.; Malhotra, B. A. Science ed. (2002), http://doi.wiley.com/10.1002/sce.10001.

7. Cian, H., Marshall, J.; Qian, M. JSTE, (2018), 10.1080/1046560X.2018.1456884.

8. Clough, M. P. Teaching and assessing the nature of science. Sci Teach. 2011,78, 56.

9. Dekorver, B. K., y Towns, M. H. JRST. 2016, doi.org/10.1002/tea.21326.

10. Dillon, J. A Review of the Research on Practical Work in School Science. 2008. Retrieved from http://www.scoreeducation.com/download s/practical_work/Review_of_Research.pdf

11. Gil-Pérez, D. y Payá, J. Rev. enseñ. fís.1988, 2, 73.

12. Gil-Pérez, D. Enseñ. Cienc. Rev. Invest. Exp. Didact. 1986, 4,111.

13. Gil Pérez, D., Valdés Castro, P. Enseñ. Cienc. Rev. Invest. Exp. Didact. 1996, $14,155$.

14. Gil Pérez, D., Martínez Torregrosa, J., \& Vilches Peña, A. A renovación do ensino universitario: necesidade, obstáculos e oportunidades. Vigo: Vicerreitoría de Formación e Innovación Educativa, Universidade de Vigo, 2008.

15. Fadzil, H. M.; Saat, R. M. EURASIA J. Math., Sci Tech. 2017, doi: 10.12973/eurasia.2017.00953a.

16. Hodson. Enseñ. Cienc. Rev. Invest. Exp. Didact.1994, 12, 299.

17. Hofstein, A., y Lunetta, V. N. Science ed., (2004), doi.org/10.1002/sce.10106.

18. Hofstein, A., Navon, O., Kipnis, M.; Mamlok-Naaman, R. JRST. (2005), doi.org/10.1002/tea.20072.

19. Irez, S. Çakir, M., Şeker, H. EFMED. 2011, 5,6 .

20. Jitendra, A. K., Petersen-Brown, S., Lein, A. E., Zaslofsky, A. F., Kunkel, A. K., Jung, P. G.; Egan, A. M. J Learn Disabil-Us. (2015), doi:10.1177/0022219413487408.

21. Kang, N.-H., y Wallace, C. S. Science ed., 
(2005). https://doi.org/10.1002/sce.20013.

22. Lazonder, A.W; Harmsen, R. RER. (2016).

DOI 10.3102/0034654315627366.

23. Lederman, N. Hanbook of research on science education, Abell, S.; Lederman, eds.; Routledge: New York, 2007, Cap. 28.

24. Lederman, N.; Lederman, J. Handbook of Research on Science Education; Abell, S.; Lederman, N., eds.; Routledge: New York, 2014 , Cap. 30.

25. Lederman, N. G., Antink, A., Bartos, S. Sci.Educ. (2014), doi.org/10.1007/s11191012-9503-3.

26. Leite, L., y Dourado, L. Procedia Soc

Behav Sci. (2013), doi.org/10.1016/j.sbspro.2013.12.190.

27. Lunetta, V. N., Hofstein, A., y Clough, M. $P$. Hanbook of research on science education, Abell, S.; Lederman, eds.; Routledge: New York, 2007, Cap. 15.

28. Millar, R. Analysing practical activities to assess and improve effectiveness: the practical activity analysis inventory (paai). York: centre for innovation and research in science education, university of york. 2009.

29. Miller, J.D. Proc. Amer. Acad. Arts.1983. $112,29$.

30. Pekbay, C.; Yilmaz, S. IJPE. 2015, 1, 113.

31. Pedaste M., Mäeots M., Siiman L.A., De Jong T., Van Riesen S.A., Kamp E.T., y Tsourlidaki E. Educ. Res. Rev. 2015, 14, 47.

32. Peltier, C., y Vannest, K. J. Rev. Educ. Res. 2017, 87, 889.

33. Sandoval, W. A., y Reiser, B. J. Science ed, (2004), doi.org/10.1002/sce.10130.

34. Schwichow, M., Zimmerman, C., Croker, S., y Härtig, H. JRST. (2016), doi: 10.1002/tea.21320.

35. Singer, S., Hilton, M. L., y Schweingruber, $H$. A.; America's lab report investigations in high school science. Eds. Committee on High School Science Laboratories: Washington, D.C, 2005.

36. Tamir, P.; García Rovira, M. P.Enseñ. Cienc. Rev. Invest. Exp. Didact. 1992,10, 3.

37. Vasques, R., Solano, I., Veit, E. A.; Lang da Silveira, F.. Rev. electrón. investig. educ. cienc. 2011, 6, 43.

38. Vilches, A.; Gil Pérez, D. TED. 2007, 22, 67.

39. Vhurumuku, E., Holtman, L., Mikalsen, O.; Kolsto, S. D. JRST. (2006), doi.org/10.1002/tea.20098.

40. Wallace, C. S., Tsoi, M. Y., Calkin, J.;
Darley, M. JRST. doi.org/10.1002/tea.10127.

(2003),

41. Yacoubian, H. A.; BouJaoude, S.. JRST, (2010), doi.org/10.1002/. 
Table 1. Number of participants and LA by subject and degree

\begin{tabular}{|c|c|c|c|c|}
\hline Degree & Subjet & $\begin{array}{l}\text { Number of } \\
\text { students } \\
\text { at the end }\end{array}$ & $\begin{array}{l}\text { Number of } \\
\text { practices }\end{array}$ & $\begin{array}{l}\text { Subject } \\
\text { semester }\end{array}$ \\
\hline \multirow[t]{3}{*}{$\begin{array}{l}\text { Mathematics and } \\
\text { Physics }\end{array}$} & $\begin{array}{l}\text { Physics of } \\
\text { movement }\end{array}$ & 14 & 7 & 1 \\
\hline & Physics of light & 10 & 8 & 6 \\
\hline & $\begin{array}{l}\text { Physics of } \\
\text { continuos } \\
\text { media }\end{array}$ & 14 & 6 & 3 \\
\hline \multirow{6}{*}{$\begin{array}{l}\text { Basic Education } \\
\text { with Emphasis } \\
\text { on Natural } \\
\text { Sciences and } \\
\text { Environmental } \\
\text { Education }\end{array}$} & Microbiology & 10 & 6 & 3 \\
\hline & Genetic & 22 & 5 & 5 \\
\hline & Ecology & 7 & 5 & 8 \\
\hline & $\begin{array}{l}\text { Chemical } \\
\text { systems II }\end{array}$ & 12 & 9 & 2 \\
\hline & $\begin{array}{l}\text { Chemical } \\
\text { systems III }\end{array}$ & 13 & 8 & 3 \\
\hline & $\begin{array}{l}\text { Chemical } \\
\text { systems IV }\end{array}$ & 14 & 3 & 4 \\
\hline Total & & 116 & 57 & \\
\hline
\end{tabular}


Table 2. Recurrences averages of actions per subject in the LAS

\begin{tabular}{|c|c|c|c|c|}
\hline Category & Activities & Recurrences & Averages & ST \\
\hline \multirow{5}{*}{ Planning } & Formulates questions & 41 & 0,72 & 1,01 \\
\hline & Predicts experimental results & 4 & 0,07 & 0,32 \\
\hline & formulates hypothesis & 17 & 0,30 & 0,50 \\
\hline & Design observations/procedures & 0 & 0,04 & 0,19 \\
\hline & $\begin{array}{l}\text { Design an experiment } \\
\text { Planing average }\end{array}$ & 0 & $\begin{array}{c}0 \\
0,22\end{array}$ & $\begin{array}{c}0 \\
0,59\end{array}$ \\
\hline \multirow{7}{*}{ Accomplishment } & Make observations & 168 & 2,95 & 2,47 \\
\hline & Make measures & 169 & 2,96 & 2,24 \\
\hline & use appliances & 156 & 2,74 & 2,50 \\
\hline & Write down results & 205 & 3,60 & 2,58 \\
\hline & Make calculations & 131 & 2,30 & 2,78 \\
\hline & Explain Procedures & 12 & 0,21 & 0,59 \\
\hline & $\begin{array}{l}\text { Work according to your own design } \\
\text { Accomplishment average }\end{array}$ & 0 & $\begin{array}{c}0 \\
2,11\end{array}$ & $\begin{array}{c}0 \\
2,50\end{array}$ \\
\hline \multirow{10}{*}{ Analyse } & Represents data in a table & 140 & 2,46 & 2,82 \\
\hline & Graph the results & 61 & 1,07 & 2,05 \\
\hline & $\begin{array}{c}\text { Make drawings based on your own } \\
\text { observations }\end{array}$ & 27 & 0,47 & 1,30 \\
\hline & $\begin{array}{c}\text { Extract interrelations and / or } \\
\text { conclusions. }\end{array}$ & 194 & 3,40 & 2,37 \\
\hline & $\begin{array}{c}\text { Determine the accuracy of the } \\
\text { experimental results } \\
\text { Define the limitations and }\end{array}$ & 95 & 1,67 & 1,92 \\
\hline & $\begin{array}{c}\text { assumptions inherent in the } \\
\text { experiment. }\end{array}$ & 53 & 0,93 & 1,51 \\
\hline & $\begin{array}{l}\text { Make generalization / propose } \\
\text { models }\end{array}$ & 1 & 0,02 & 0,13 \\
\hline & Explain interrelations & 64 & 1,19 & 1,72 \\
\hline & Formulates new questions & 5 & 0,09 & 0,34 \\
\hline & Analyse average & & 1,25 & 2,05 \\
\hline \multirow{5}{*}{ Enforcement } & $\begin{array}{l}\text { Makes predictions based on } \\
\text { experimental results }\end{array}$ & 0 & 0 & 0,00 \\
\hline & $\begin{array}{c}\text { Formulates hypotheses based on } \\
\text { experimental results }\end{array}$ & 4 & 0,07 & 0,32 \\
\hline & $\begin{array}{l}\text { Apply experimental techniques to a } \\
\text { new problem }\end{array}$ & 0 & 0 & 0,00 \\
\hline & $\begin{array}{l}\text { Apply the experimental results to a } \\
\text { new context }\end{array}$ & 5 & 0,09 & 0,39 \\
\hline & Enforcement average & & 0,05 & 0,27 \\
\hline
\end{tabular}


Table 3. averages per subject and semester

\begin{tabular}{|c|c|c|c|c|c|c|c|c|c|c|c|c|c|c|c|c|c|c|}
\hline & \multicolumn{6}{|c|}{ Semestre } & \multicolumn{12}{|c|}{ Semestre } \\
\hline & \multicolumn{2}{|c|}{1} & \multicolumn{2}{|c|}{3} & \multicolumn{2}{|c|}{6} & \multicolumn{2}{|c|}{2} & \multicolumn{2}{|c|}{ M3 } & \multicolumn{2}{|c|}{ Q3 } & \multicolumn{2}{|c|}{4} & \multicolumn{2}{|c|}{5} & \multicolumn{2}{|c|}{8} \\
\hline & $M$ & $D T$ & $M$ & $D T$ & $\mathrm{M}$ & $D T$ & $M$ & $D T$ & $\mathrm{M}$ & $D T$ & $M$ & $D T$ & $M$ & $D T$ & $\mathrm{M}$ & $D T$ & $\mathrm{M}$ & $D T$ \\
\hline \multicolumn{19}{|l|}{ Planning } \\
\hline Ask questions & 0,57 & 0,53 & 0,17 & 0,41 & 1,00 & 0,76 & 0,20 & 0,40 & 0,17 & 0,41 & 1,13 & 1,36 & 2,00 & 2,65 & 0,80 & 0,84 & 1,20 & 1,10 \\
\hline Formulates questions & 0,14 & 0,38 & 0,00 & 0,00 & 0,13 & 0,35 & 0,20 & 0,70 & 0,00 & 0,00 & 0,00 & 0,00 & 0,00 & 0,00 & 0,00 & 0,00 & 0,00 & 0,00 \\
\hline formulates hypothesis & 0,57 & 0,53 & 0,17 & 0,41 & 0,25 & 0,71 & 0,20 & 0,40 & 0,17 & 0,41 & 0,38 & 0,52 & 0,33 & 0,58 & 0,00 & 0,00 & 0,60 & 0,55 \\
\hline $\begin{array}{l}\text { Design } \\
\text { observations/procedures }\end{array}$ & 0,14 & 0,38 & 0,00 & 0,00 & 0,13 & 0,35 & 0,00 & 0,00 & 0,00 & 0,00 & 0,00 & 0,00 & 0,00 & 0,00 & 0,00 & 0,00 & 0,00 & 0,00 \\
\hline Design an experiment & 0,00 & 0,00 & 0,00 & 0,00 & 0,00 & 0,00 & 0,00 & 0,00 & 0,00 & 0,00 & 0,00 & 0,00 & 0,00 & 0,00 & 0,00 & 0,00 & 0,00 & 0,00 \\
\hline \multicolumn{19}{|l|}{ Accomplishment } \\
\hline Make observations & 2,14 & 1,95 & 2,33 & 1,63 & 3,00 & 2,07 & 3,20 & 1,90 & 2,50 & 1,76 & 2,50 & 2,00 & 7,00 & 7,55 & 3,60 & 1,52 & 2,40 & 2,07 \\
\hline Make measures & 3,00 & 1,83 & 3,50 & 1,38 & 2,00 & 1,41 & 3,20 & 1,60 & 1,17 & 1,83 & 3,38 & 1,60 & 6,33 & 2,52 & 0,20 & 0,45 & 5,60 & 2,70 \\
\hline use appliances & 2,71 & 1,60 & 1,83 & 0,98 & 2,00 & 0,93 & 2,30 & 1,40 & 2,33 & 1,63 & 2,88 & 0,99 & 9,67 & 5,69 & 2,00 & 0,71 & 2,60 & 3,97 \\
\hline Write down results & 4,14 & 0,90 & 3,83 & 1,60 & 3,63 & 1,69 & 3,90 & 1,60 & 0,17 & 0,41 & 3,38 & 2,20 & 8,67 & 3,51 & 0,80 & 1,79 & 6,20 & 2,17 \\
\hline Make calculations & 2,57 & 1,99 & 0,83 & 0,98 & 3,75 & 1,75 & 1,40 & 2,40 & 0,00 & 0,00 & 2,75 & 2,49 & 6,67 & 7,64 & 2,00 & 2,74 & 2,60 & 2,07 \\
\hline Explain Procedures & 0,00 & 0,00 & 0,00 & 0,00 & 0,13 & 0,35 & 0,30 & 0,50 & 0,00 & 0,00 & 0,63 & 0,92 & 0,00 & 0,00 & 0,60 & 1,34 & 0,00 & 0,00 \\
\hline $\begin{array}{l}\text { Work according to your own } \\
\text { design }\end{array}$ & 0,00 & 0,00 & 0,00 & 0,00 & 0,00 & 0,00 & 0,00 & 0,00 & 0,00 & 0,00 & 0,00 & 0,00 & 0,00 & 0,00 & 0,00 & 0,00 & 0,00 & 0,00 \\
\hline \multicolumn{19}{|l|}{ Analyse } \\
\hline Represents data in a table & 3,00 & 2,08 & 1,17 & 1,47 & 1,38 & 1,60 & 3,10 & 2,80 & 1,67 & 1,86 & 1,13 & 2,10 & 8,67 & 5,51 & 2,00 & 2,74 & 3,60 & 2,30 \\
\hline Graph the results & 2,86 & 3,18 & 0,67 & 1,03 & 0,13 & 0,35 & 0,00 & 0,00 & 0,00 & 0,00 & 0,88 & 1,81 & 3,67 & 1,53 & 0,00 & 0,00 & 3,60 & 2,97 \\
\hline $\begin{array}{l}\text { Make drawings based on } \\
\text { your own observations }\end{array}$ & 0,43 & 1,13 & 0,33 & 0,52 & 0,63 & 1,19 & 0,80 & 2,30 & 0,50 & 0,84 & 0,00 & 0,00 & 0,00 & 0,00 & 1,00 & 2,24 & 0,40 & 0,89 \\
\hline $\begin{array}{l}\text { Extract interrelations and / or } \\
\text { conclusions. }\end{array}$ & 4,00 & 1,53 & 2,17 & 1,33 & 2,38 & 1,30 & 5,30 & 3,20 & 1,83 & 2,23 & 3,25 & 2,25 & 5,00 & 2,00 & 2,00 & 2,74 & 4,80 & 0,45 \\
\hline $\begin{array}{l}\text { Determine the accuracy of } \\
\text { the experimental results }\end{array}$ & 3,57 & 1,99 & 1,50 & 1,22 & 1,75 & 1,49 & 0,90 & 1,80 & 0,33 & 0,82 & 2,88 & 2,47 & 3,33 & 1,53 & 0,40 & 0,55 & 0,40 & 0,89 \\
\hline $\begin{array}{l}\text { Define the limitations and } \\
\text { assumptions inherent in the } \\
\text { experiment }\end{array}$ & 3,43 & 1,72 & 1,00 & 1,26 & 0,38 & 0,52 & 0,80 & 1,60 & 0,17 & 0,41 & 0,50 & 1,07 & 2,67 & 1,15 & 0,00 & 0,00 & 0,00 & 0,00 \\
\hline $\begin{array}{l}\text { Make generalization / } \\
\text { propose models }\end{array}$ & 0,14 & 0,38 & 0,00 & 0,00 & 0,00 & 0,00 & 0,00 & 0,00 & 0,00 & 0,00 & 0,00 & 0,00 & 0,00 & 0,00 & 0,00 & 0,00 & 0,00 & 0,00 \\
\hline Explain interrelations & 1,43 & 1,81 & 0,33 & 0,82 & 0,50 & 0,76 & 3,10 & 2,40 & 0,00 & 0,00 & 1,00 & 1,41 & 2,33 & 0,58 & 1,00 & 1,41 & 0,80 & 1,79 \\
\hline Formulates new questions & 0,29 & 0,49 & 0,00 & 0,00 & 0,00 & 0,00 & 0,00 & 0,00 & 0,00 & 0,00 & 0,00 & 0,00 & 0,67 & 1,15 & 0,20 & 0,45 & 0,00 & 0,00 \\
\hline \multicolumn{19}{|l|}{ Enforcement } \\
\hline $\begin{array}{l}\text { Makes predictions based on } \\
\text { experimental results }\end{array}$ & 0,00 & 0,00 & 0,00 & 0,00 & 0,00 & 0,00 & 0,00 & 0,00 & 0,00 & 0,00 & 0,00 & 0,00 & 0,00 & 0,00 & 0,00 & 0,00 & 0,00 & 0,00 \\
\hline $\begin{array}{l}\text { Formulates hypotheses } \\
\text { based on experimental } \\
\text { results }\end{array}$ & 0,14 & 0,38 & 0,00 & 0,00 & 0,00 & 0,00 & 0,20 & 0,70 & 0,00 & 0,00 & 0,00 & 0,00 & 0,00 & 0,00 & 0,00 & 0,00 & 0,20 & 0,45 \\
\hline $\begin{array}{l}\text { Apply experimental } \\
\text { techniques to a new problem }\end{array}$ & 0,00 & 0,00 & 0,00 & 0,00 & 0,00 & 0,00 & 0,00 & 0,00 & 0,00 & 0,00 & 0,00 & 0,00 & 0,00 & 0,00 & 0,00 & 0,00 & 0,00 & 0,00 \\
\hline $\begin{array}{l}\text { Apply the experimental } \\
\text { results to a new context }\end{array}$ & 0,29 & 0,76 & 0,00 & 0,00 & 0,00 & 0,00 & 0,20 & 0,70 & 0,00 & 0,00 & 0,00 & 0,00 & 0,00 & 0,00 & 0,20 & 0,45 & 0,00 & 0,00 \\
\hline
\end{tabular}


Table 4. Averages and Typical Deviation in Nature of Science and in each category of Laboratory activities, by subject

\begin{tabular}{|c|c|c|c|c|c|c|c|c|c|c|c|}
\hline \multirow[t]{2}{*}{ Subjects } & \multirow[t]{2}{*}{ Semest } & \multicolumn{2}{|c|}{ NOS } & \multicolumn{8}{|c|}{ LAB Activities } \\
\hline & & Average & $S T$ & Planning & ST & Accomplishment & ST & Analyse & ST & Enforcement & ST \\
\hline Physics of movement & 1 & 2,98 & 0,60 & 0,29 & 0,46 & 2,08 & 1,98 & 2,13 & 2,22 & 0,11 & 0,41 \\
\hline Chemical systems II & 2 & 2,75 & 0,40 & 0,13 & 0,40 & 2,06 & 2,02 & 1,56 & 2,63 & 0,11 & 0,35 \\
\hline Microbiology & 3 & 2,73 & 0,64 & 0,07 & 0,26 & 1,62 & 1.80 & 0,90 & 1,16 & 0,00 & 0,00 \\
\hline Chemical systems III & 3 & 2,89 & 0,45 & 0,30 & 0,76 & 2,21 & 2,02 & 1,07 & 1,87 & 0,00 & 0,00 \\
\hline $\begin{array}{l}\text { Physics of continuos } \\
\text { media }\end{array}$ & 3 & 2,97 & 0,33 & 0,07 & 0,25 & 1,76 & 1,81 & 0,80 & 1,16 & 0,00 & 0,00 \\
\hline Chemical systems IV & 4 & 3,06 & 0,37 & 0,47 & 1,30 & 5,48 & 5,52 & 2,93 & 3,20 & 0,00 & 0,00 \\
\hline Genetic & 5 & 3,29 & 0,81 & 0,16 & 0,47 & 1,31 & 1,81 & 0,73 & 1,63 & 0,05 & 0,22 \\
\hline Physics of light & 6 & 2,69 & 0,24 & 0,30 & 0,61 & 2,07 & 1,93 & 0,79 & 1,23 & 0,00 & 0,00 \\
\hline Ecology & 8 & 3,61 & 0,61 & 0,36 & 0,7 & 2,77 & 3,08 & 1,39 & 2,25 & 0,05 & 0,22 \\
\hline
\end{tabular}

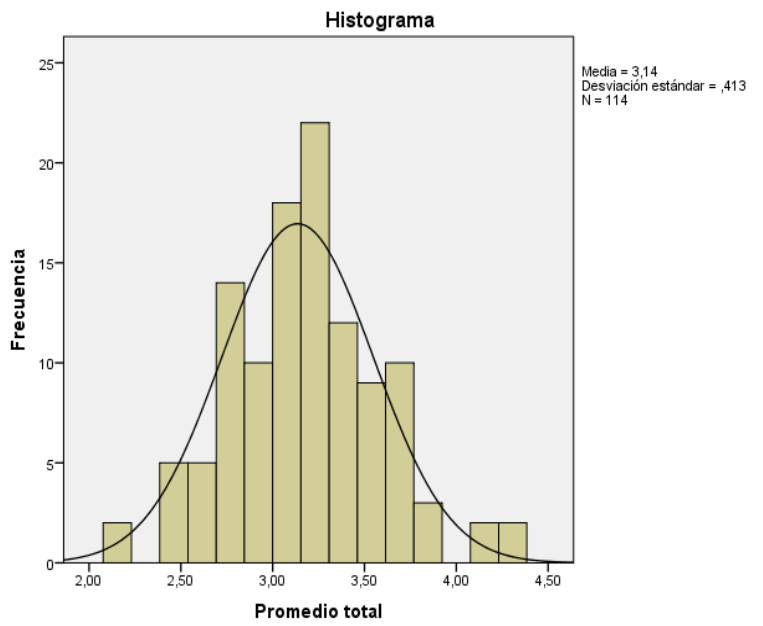

Figure 1. Distribution of NOS averages in trainee teachers

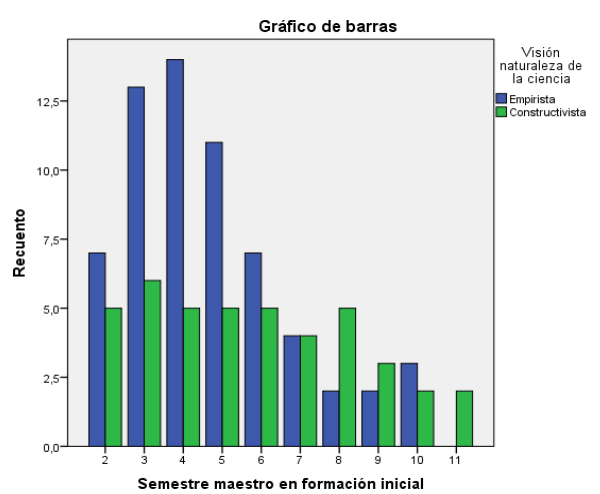

Figure 2. Distribution of the NOS vision according to the semester of the teacher in training

Periódico Tchê Química. ISSN 2179-0302. (2019); vol.16 (n`32)

Downloaded from www.periodico.tchequimica.com 